\title{
Metode persalinan dan hubungannya dengan inisiasi menyusu dini di RSUP Dr. Sardjito Yogyakarta
}

Sheilla Virarisca', Djaswadi Dasuki², Sulchan Sofoewan ${ }^{2}$

\begin{abstract}
Background: The 2002-2003 IDHS shows that the presentation of breastfeeding within an hour after birth or early initiation in Indonesia is still low (38\%). According to some studies, early initiation plays an important role in reducing infant mortality rate, determining the success of exclusive breastfeeding, preventing pre-lactation feeding, creating more intensive bonding between mother and baby. Some earlier studies state that delivery methods are related with early initiation. However, there have been some studies whose results are in contrast with those previous studies.

Objective: To study the relationship between delivery methods and early initiation in Dr. Sardjito hospital, Yogyakarta. Method: This was an observational study with a cross-sectional study design through quantitative and qualitative approaches. Samples were postpartum women in Dr. Sardjito hospital as many as 100 respondents. Data were analyzed with univariable analysis using frequency distribution table, bivariable analysis using chi-square, and multivariable analysis using binary regression.

Results: The proportion of early initiation of breastfeeding was three times greater in women who gave birth with normal delivery methods than women who gave birth with cesarean section (RR=3.1; 95\% Cl=1.42-6.89). Another factor that was related with early initiation of breastfeding was the support from health providers $(R R=2.3 ; 95 \% \mathrm{Cl}=1.36-3.78)$. Meanwhile, women's age, knowledge, parity, economic status, and mother's disease were insignificantly related with early initiation.

Conclusion: The proportion of early initiation of breastfeeding was three times greater in women who gave birth with normal delivery methods than women who gave birth with cesarean section. Another factor that was related with early initiation of breastfeeding was the support from health providers. Meanwhile, women's age, knowledge, parity, economic status, and disease were insignificantly related with early initiation of breastfeeding.
\end{abstract}

KEY WORDS early initiation, normal delivery, cesarean sec

\section{PENDAHULUAN}

Data menunjukkan bahwa di Indonesia, persentase pemberian Air Susu Ibu (ASI) dalam 1 jam pertama setelah bayi dilahirkan masih rendah yaitu sebesar 38\% (1). Angka tersebut masih jauh tertinggal bila dibandingkan dengan negara-negara berkembang lainnya seperti Oman (85\%), Srilangka (75\%), Filipina (54\%), dan Turki (54\%) (2). Inisiasi Menyusu Dini (IMD) atau yang biasa disebut dengan early latch on/breast crawl adalah kemampuan bayi untuk menyusu sendiri segera setelah lahir, yaitu dalam waktu 60 menit atau 1 jam pertama setelah bayi dilahirkan.

Setiap bayi yang baru lahir mempunyai kemampuan untuk mulai menyusu sendiri dan menemukan puting susu ibunya, dengan syarat setelah lahir bayi tersebut segera diletakkan di atas dada ibu dan terjadi kontak antara kulit bayi dengan kulit ibu atau skin to skin contact. Semua tindakan invasif pada bayi, seperti suntikan vitamin $\mathrm{K}$ dan pemberian tetes mata untuk mencegah gonore yang umumnya diberikan setelah bayi lahir dapat ditunda setidaknya selama satu jam sampai bayi dapat menyusu sendiri $(3,4,5)$.

Penundaan IMD merupakan faktor risiko yang dapat meningkatkan kematian neonatus sebesar $2,4 \%$. Penelitian tersebut menyatakan bahwa IMD dapat mengurangi angka kematian neonatus sebesar $22 \%$. Sedangkan bila menyusu dimulai setelah 1 jam pertama kelahiran tetapi belum lewat dari 24 jam, hanya dapat mengurangi angka kematian neonatus sebesar (16\%) (6). Selain dapat menekan angka kematian neonatus, IMD juga terbukti berperan dalam kesuksesan proses menyusui selanjutnya $(7,8)$. Manfaat lain yang bisa diperoleh IMD adalah meningkatnya jalinan kasih sayang antara ibu dan bayi (bonding) $(3,9)$. Hubungan emosional yang erat, kontak kulit, rangsangan visual, dan pendengaran yang terjadi pada saat proses IMD juga membantu merangsang produksi hormon oksitosin yang berperan dalam kontraksi uterus setelah melahirkan, sehingga akan membantu mengurangi perdarahan. Kadar hormon oksitosin pada saat IMD akan lebih meningkat secara signifikan (10).

Ada beberapa intervensi yang dapat mempengaruhi kemampuan alami bayi untuk IMD di antaranya yaitu: 1) obat-obatan kimiawi yang diberikan saat ibu melahirkan, karena obat-obatan ini bisa sampai ke janin melalui ari-ari dan mungkin menyebabkan bayi sulit menyusui pada payudara ibu, 2) kelahiran dengan obat-obatan atau tindakan seperti seksio sesarea, vakum, forsep, rasa sakit karena episiotomi, dan 3) dukungan petugas kesehatan karena tidak semua petugas kesehatan telah

1 BKKBN Pusat Jakarta, e-mail: dr_celavira@yahoo.com

${ }^{2}$ Bagian Obstetri dan Ginekologi, Fakultas Kedokteran Universitas Gadjah Mada, Yogyakarta. 
mendapatkan informasi mengenai IMD dan tidak semua petugas kesehatan bersedia memfasilitasi IMD (3). Hasil penelitian yang menggunakan data Survei Demografi Kesehatan Indonesia (SDKI) tahun 2007 menemukan bahwa perawatan pascapersalinan di fasilitas pelayanan kesehatan dengan pertolongan tenaga kesehatan yang dianggap paling terampil, khususnya di rumah sakit, tidak berhubungan secara positif dengan perilaku ibu untuk menyusui bayinya, tetapi justru berpengaruh negatif (11). Beberapa penelitian yang pernah dilakukan menyatakan bahwa IMD dipengaruhi oleh beberapa faktor dan di antaranya yaitu faktor metode persalinan $(12,13,14)$. Namun ada beberapa penelitian yang bertolak belakang dengan hasil penelitian tersebut $(15,16)$.

Di Indonesia, bayi yang dilahirkan dengan metode persalinan seksio sesarea pada umumnya tidak difasilitasi untuk melakukan IMD, padahal IMD merupakan rekomendasi internasional dari UNICEF-WHO tahun 1992, yang isinya telah dikembangkan oleh Departemen Kesehatan RI. Rekomendasi tersebut menyatakan agar semua sarana pelayanan kesehatan menerapkan 10 Langkah Menuju Keberhasilan Menyusui (LMKM)/ Ten Step to Successful Breastfeeding yang salah satu isinya menganjurkan untuk membantu para ibu dalam pelaksanaan IMD setelah melahirkan, baik yang melahirkan dengan metode normal pervaginam maupun dengan seksio sesaera (4).

Sebenarnya pada post partum seksio sesarea, jika ibu diberikan anestesi spinal atau epidural di mana ibu masih dalam keadaan sadar, maka ibu dapat segera memberi respon pada bayi. Jika IMD belum dilakukan di kamar bersalin, kamar operasi atau bayi harus dipindah sebelum satu jam, maka bayi tetap diletakkan di dada ibu ketika dipindahkan ke kamar pemulihan atau kamar perawatan. Hal tersebut bertujuan agar menyusu selanjutnya bisa dilakukan di kamar pemulihan maupun di kamar perawatan. Ibu yang mendapatkan anestesi umum, kontak dengan bayi dapat terjadi di ruang pemulihan, yaitu saat ibu sudah dapat merespon. Ayah dapat menggantikan ibu untuk memberikan kontak kulit dengan kulit sehingga bayi tetap hangat sampai ibu kembali sadar $(3,5)$.

Mengingat besarnya peran IMD dalam menekan angka kematian bayi dan rendahnya prevalensi IMD di Provinsi DI Yogyakarta, serta masih adanya perbedaan pada hasil penelitian-penelitian sebelumnya, maka tujuan penelitian ini adalah untuk mengetahui hubungan antara metode persalinan dengan inisiasi menyusu dini di RSUP Dr. Sardjito Yogyakarta.

\section{BAHAN DAN METODE}

Penelitian ini menggunakan pendekatan kuantitatif dan kualitatif dengan rancangan cross sectional, yaitu mencari hubungan antara variabel bebas (metode persalinan) dengan variabel tergantung (inisiasi menyusu dini) dengan melakukan pengukuran sesaat. Selain itu juga dilengkapi dengan data kualitatif menggunakan wawancara mendalam. Variabel lain yang diteliti adalah variabel umur ibu, pengetahuan ibu tentang IMD, paritas, ada atau tidaknya penyakit ibu, dan dukungan tenaga kesehatan yaitu Dokter Spesialis Obstetri Ginekologi (SpOG) dan Bidan.

Populasi dalam penelitian ini adalah ibu postpartum yang melahirkan di RSUP Dr. Sardjito Yogyakarta pada bulan November 2008 sampai dengan Januari 2009. Besar sampel dalam penelitian ini sebanyak 100 orang subjek yang diperoleh berdasarkan rumus pengujian hipotesis untuk dua proporsi populasi, dengan tingkat kepercayaan sebesar 0,05 $(1,96)$, kekuatan penelitian sebesar $80 \%$ $(0,842)$, proporsi inisiasi menyusu dini pada seksio sesarea sebesar 0,07, serta proporsi inisiasi menyusu dini pada persalinan pervaginam sebesar 0,3 (17).

Subjek penelitian adalah ibu postpartum yang melahirkan di RSUP Dr. Sardjito, berusia 15-49 tahun, post partum normal atau seksio sesarea, melahirkan anak pertama atau lebih dan bersedia menjadi subjek penelitian. Kriteria eksklusi yaitu ibu yang melahirkan dengan bantuan forsep atau vakum, mengalami komplikasi persalinan (perdarahan), dan ibu yang bayinya mengalami kelainan kongenital. Teknik pengambilan sampel dalam penelitian ini menggunakan teknik consecutive sampling, yaitu semua subjek yang datang dan memenuhi kriteria pemilihan diikutsertakan dalam penelitian sampai jumlah subjek yang diperlukan terpenuhi. Pengambilan sampel penelitian dilakukan di ruangan rawat inap kebidanan RSUP Dr. Sardjito Yogyakarta.

Pelaksanaan penelitian dilakukan dengan pengambilan data dengan menggunakan instrumen penelitian berupa uji kuesioner. Variabel dukungan tenaga kesehatan dinilai berdasarkan hasil jawaban subjek dari pertanyaan kuesioner tentang dukungan tenaga kesehatan dalam inisiasi menyusu dini yang terdiri dari 4 pertanyaan dengan skor 1-8. Dengan persentil $50 \%$ diperoleh cut off point 5 . Dukungan tenaga kesehatan dikategorikan menjadi tinggi dan rendah, yaitu dikatakan tinggi apabila skor yang diperoleh sama atau lebih besar dari 5 dan rendah apabila skor lebih kecil dari 5. Variabel pengetahuan diperoleh berdasarkan hasil jawaban responden dari pertanyaan kuesioner pengetahuan tentang inisiasi menyusu dini. Terdiri dari 6 pertanyaan dengan skor 1-12. Dengan persentil $50 \%$ diperoleh cut off point 11 . Variabel pengetahuan dikategorikan menjadi tinggi dan rendah, yaitu dikatakan tinggi apabila skor lebih besar atau sama dengan 11 dan dikatakan rendah apabila skor lebih kecil dari 11.

Pengumpulan data kualitatif dilakukan dengan menggunakan metode wawancara mendalam kepada 8 orang subjek penelitian yang terlibat dalam pengisian kuesioner dan 6 orang tenaga kesehatan dengan kualifikasi Dokter Spesialis Obstetri-Ginekologi dan D3 
kebidanan. Hasil wawancara mendalam direkam dan kemudian dibuat transkrip untuk dilakukan analisis. Analisis data kualitatif dalam penelitian ini dilakukan dengan tujuan untuk memperkuat analisis data kuantitatif.

Uji Chi-square dilakukan untuk mengetahui proporsi IMD pada wanita yang melahirkan dengan persalinan pervaginam dibandingkan dengan wanita yang melahirkan dengan seksio sesarea. Selain itu juga untuk menganalisis variabel lain yang diteliti yaitu pengetahuan, penyakit, dan dukungan tenaga kesehatan. Analisis bivariat merupakan analisis yang digunakan untuk melihat hubungan antara dua variabel. Pada tahap ini dilakukan analisis variabel bebas dan variabel luar dengan variabel terikat. Selanjutnya dilakukan pula analisis antara variabel luar dengan variabel bebas. Uji statistik yang digunakan dengan cara tabel silang, uji hipotesis (nilai $p$ value), estimasi interval kepercayaan (confidence interval) serta menghitung RP (Ratio Prevalence). Analisis multivariat menggunakan regresi binomial dilakukan dengan tujuan untuk melihat hubungan metode persalinan dengan IMD dan untuk melihat variabel lain yang ikut berpengaruh terhadap IMD.

\section{HASIL DAN BAHASAN}

Tabel 1 memperlihatkan proporsi subjek yang melahirkan dengan metode persalinan pervaginam lebih besar (65\%), dibandingkan subjek yang melahirkan dengan metode persalinan seksio sesarea. Subjek yang berhasil IMD sebesar $51 \%$. Sebagian besar subjek mendapatkan dukungan tenaga kesehatan yang rendah (52\%). Sebagian besar subjek juga tidak menderita penyakit semasa hamil (87\%). Berdasarkan sisi pengetahuan tentang IMD, terlihat bahwa lebih banyak subyek yang memiliki pengetahuan tinggi (55\%).

\section{Analisis bivariat}

Hasil analisis menunjukkan bahwa variabel metode persalinan menunjukkan hubungan bermakna secara
Tabel 1. Distribusi frekuensi karakteristik subjek penelitian

\begin{tabular}{lcc}
\hline Karakteristik subjek penelitian & $\mathbf{n = 1 0 0}$ & $\%$ \\
\hline Inisiasi menyusu dini & & \\
$\quad \leq 60$ menit & 51 & 51,0 \\
$\quad$ >60 menit & 49 & 49,0 \\
Metode persalinan & & \\
$\quad$ Persalinan pervaginam & 65 & 65,0 \\
$\quad$ Sesarea & 35 & 35,0 \\
Pengetahuan & 55 & 55,0 \\
$\quad$ Tinggi & 45 & 45,0 \\
$\quad$ Rendah & & \\
Ada tidaknya penyakit ibu selama & & \\
hamil & 87 & 87,0 \\
$\quad$ Tidak & 13 & 13,0 \\
$\quad$ Ya & & \\
Dukungan tenaga kesehatan & 48 & 48,0 \\
$\quad$ Tinggi & 52 & 52,0 \\
$\quad$ Rendah &
\end{tabular}

praktis dan statistik dengan IMD dengan nilai RP sebesar 4,$9 ; 95 \% \mathrm{Cl}=2,16-11,31$. Selain variabel metode persalinan ada 2 variabel lain yang memperlihatkan hubungan yang bermakna secara praktis dan statistik dengan IMD, yaitu variabel penyakit ibu dengan nilai RP sebesar 3,6; $95 \% \mathrm{Cl}=1,39-2,70$ dan dukungan tenaga kesehatan dengan nilai $\mathrm{RP}$ sebesar 3,$5 ; 95 \% \mathrm{Cl}=2,10-5,88$. Variabel pengetahuan tidak memiliki hubungan bermakna secara statistik dengan IMD karena mempunyai p lebih dari 0,05. Analisis bivariat variabel bebas dan variabel luar terhadap variabel terikat dapat dilihat pada Tabel 2.

Selain analisis bivariat terhadap variabel terikat, dilakukan pula analisis bivariat antara variabel luar dengan variabel bebas. Hasil analisis ini menunjukkan bahwa hanya variabel penyakit ibu dan dukungan tenaga kesehatan yang menunjukkan hubungan bermakna secara praktis dan statistik dengan metode persalinan. Variabel penyakit ibu nilai RP sebesar $2,2(95 \% \mathrm{Cl}=1,43-3,76)$ dan variabel dukungan tenaga kesehatan menghasilkan nilai RP sebesar 1,6 (95\% Cl=1,19-2,20). Variabel penyakit ibu dan dukungan tenaga kesehatan dicurigai sebagai variabel

Tabel 2. Analisis Chi-square metode persalinan, pengetahuan, penyakit ibu, dan dukungan tenaga kesehatan terhadap inisiasi menyusui dini

\begin{tabular}{|c|c|c|c|c|c|c|c|c|}
\hline \multirow{3}{*}{ Variabel } & \multicolumn{4}{|c|}{ Inisiasi menyusu dini } & \multirow{3}{*}{$\chi^{2}$} & \multirow{3}{*}{$\mathbf{p}$} & \multirow{3}{*}{ RP } & \multirow{3}{*}{$95 \% \mathrm{Cl}$} \\
\hline & \multicolumn{2}{|c|}{$\leq 60$ menit } & \multicolumn{2}{|c|}{$>60$ menit } & & & & \\
\hline & $n=51$ & $\%$ & $n=49$ & $\%$ & & & & \\
\hline \multicolumn{9}{|l|}{ Metode persalinan } \\
\hline $\begin{array}{l}\text { Pervaginam } \\
\text { Seksia }\end{array}$ & 46 & 70,7 & 19 & 29,2 & 26,83 & 0,00 & 4,9 & $2,16-11,31$ \\
\hline Seksio sesarea & 5 & 14,2 & 30 & 85,7 & & & & \\
\hline \multicolumn{9}{|l|}{ Pengetahuan } \\
\hline Tinggi & 29 & 52,7 & 26 & 47,2 & 0,03 & 0,85 & 1,0 & $0,73-1,59$ \\
\hline Rendah & 22 & 48,8 & 23 & 51,1 & & & & \\
\hline \multicolumn{9}{|c|}{$\begin{array}{l}\text { Ada atau tidaknya penyakit ibu semasa } \\
\text { hamil }\end{array}$} \\
\hline Tidak & 49 & 56,3 & 38 & 43,6 & 6,03 & 0,01 & 3,6 & $1,39-2,70$ \\
\hline Ya & 2 & 15,3 & 11 & 84,6 & & & & \\
\hline \multicolumn{9}{|l|}{ Dukungan tenaga kesehatan } \\
\hline Tinggi & 39 & 81,2 & 9 & 18,7 & 31,5 & 0,00 & 3,5 & $2,10-5,88$ \\
\hline Rendah & 12 & 23,0 & 40 & 76,9 & & & & \\
\hline
\end{tabular}


pengganggu, karena pada analisis bivariat keduanya mempunyai hubungan bermakna dengan variabel bebas dan variabel terikat. Namun setelah dilakukan analisis permodelan dengan regresi, kedua variabel tersebut bukan merupakan variabel pengganggu.

\section{Analisis multivariat}

Analisis multivariat dilakukan untuk melihat hubungan antara metode persalinan dengan IMD secara simultan setelah mengontrol variabel-variabel penyakit ibu dan dukungan tenaga kesehatan. Uji yang digunakan adalah analisis regresi binomial dengan tingkat kemaknaan $p$ kurang dari 0,05. Pada analisis multivariat hanya variabel yang bermakna dari analisis bivariat yang dianalisis. Hasil analisis regresi binomial disajikan dalam Tabel 3.

\section{Analisis model 2}

Pada model ini hubungan metode persalinan dan IMD setelah dikontrol dengan variabel penyakit ibu hasilnya tetap bermakna $(\mathrm{RR}=4,3 ; 95 \% \mathrm{Cl}=1,91-10,01)$, artinya proporsi IMD lebih besar 4,3 kali pada wanita yang melahirkan dengan metode persalinan pervaginam dibandingkan pada wanita yang melahirkan dengan metode persalinan seksio sesarea. Model ini dapat memprediksi IMD sebesar $24 \%$. Hal ini ditunjukkan oleh nilai $\mathrm{R}^{2}$ (koefisien determinasi) yaitu 0,2471 , artinya sebesar $24 \%$ dapat dijelaskan oleh variabel metode persalinan, penyakit ibu, dan dukungan tenaga kesehatan dalam memprediksi pelaksanaan IMD. Terdapat 0,76 (76\%) faktor lain yang berhubungan dengan IMD yang tidak dimasukkan dalam analisis model 2.

Tabel 3. Analisis Binary Regression hubungan metode persalinan dengan inisiasi menyusui dini setelah mengontrol variabel penyakit ibu dan dukungan tenaga kesehatan

\begin{tabular}{|c|c|c|c|c|}
\hline \multirow[b]{2}{*}{ Variabel } & \multicolumn{4}{|c|}{ Inisiasi menyusu dini } \\
\hline & $\begin{array}{c}\text { Model } 1 \\
\text { RR (Cl 95\%) }\end{array}$ & $\begin{array}{c}\text { Model } 2 \\
\text { RR (Cl 95\%) }\end{array}$ & $\begin{array}{c}\text { Model } 3 \\
\text { RR (CI 95\%) }\end{array}$ & $\begin{array}{c}\text { Model } 4 \\
\text { RR (Cl 95\%) }\end{array}$ \\
\hline \multicolumn{5}{|l|}{ Metode persalinan } \\
\hline Persalinan pervaginam & $\begin{array}{c}4,9^{*} \\
(2,16-11,31)\end{array}$ & $\begin{array}{c}4,3^{*} \\
(1,91-10,01)\end{array}$ & $\begin{array}{c}3,3^{*} \\
(1,46-7,02)\end{array}$ & $\begin{array}{c}3,1^{*} \\
(1,42-6,89)\end{array}$ \\
\hline Seksio sesarea & 1 & 1 & 1 & 1 \\
\hline Penyakit ibu & & & & \\
\hline Tidak & & $\begin{array}{c}1,9 \\
(0,63-6,06)\end{array}$ & & $\begin{array}{c}1,2 \\
(0,34-4,16)\end{array}$ \\
\hline Ya & & 1 & & 1 \\
\hline \multicolumn{5}{|l|}{ Dukungan tenaga kesehatan } \\
\hline Tinggi & & & $\begin{array}{c}2,3^{*} \\
(1,44-3,76)\end{array}$ & $\begin{array}{c}2,2^{*} \\
(1,36-3,78)\end{array}$ \\
\hline Rendah & & & 1 & 1 \\
\hline Deviance & 107,254 & 105,192 & 88,555 & 88,483 \\
\hline & 0,2261 & 0,2471 & 0,4068 & 0,4069 \\
\hline $\mathrm{n}$ & 100 & 100 & 100 & 100 \\
\hline
\end{tabular}

Keterangan :

RR : Ratio Risk

95\% $\mathrm{Cl}: 95 \%$ Confidence Interval

* = signifikan $(p<0,05)$

\section{Analisis model 1}

Model 1 menunjukkan hubungan metode persalinan dengan IMD. Hasil analisis statistik menunjukkan adanya hubungan bermakna antara metode persalinan dengan IMD ( $R R=4,9 ; 95 \% \mathrm{Cl}=2,16-11,31)$, artinya proporsi IMD lebih besar 4,9 kali pada wanita yang melahirkan dengan metode persalinan pervaginam dibandingkan dengan metode persalinan seksio sesarea, Model ini dapat memprediksi IMD sebesar $22 \%$. Hal ini ditunjukkan oleh nilai $R^{2}$ (koefisien determinasi) yaitu 0,2261 , artinya sebesar $22 \%$ dapat dijelaskan oleh variabel metode persalinan dalam memprediksi pelaksana IMD. Terdapat $0,78(78 \%)$ faktor lain di luar metode persalinan yang berhubungan dengan IMD yang tidak dimasukkan dalam analisis model 1 .

\section{Analisis model 3}

Model 3 menunjukkan hubungan variabel metode persalinan dan IMD, serta besarnya kontribusi variabel luar (dukungan tenaga kesehatan). Pada model ini hubungan metode persalinan dan IMD setelah dikontrol dengan variabel dukungan tenaga kesehatan hasilnya tetap bermakna $(\mathrm{RR}=3,3 ; 95 \% \mathrm{Cl}=1,46-7,02)$, artinya proporsi IMD lebih besar 3,3 kali pada wanita yang melahirkan dengan metode persalinan pervaginam dibandingkan pada wanita yang melahirkan dengan metode persalinan seksio sesarea. Model ini dapat memprediksi IMD sebesar $40 \%$. Hal ini ditunjukkan oleh nilai $\mathrm{R}^{2}$ (koefisien determinasi) yaitu 0,4068, artinya sebesar $40 \%$ dapat dijelaskan oleh variabel metode persalinan dan dukungan tenaga kesehatan dalam memprediksi pelaksanaan IMD. Terdapat 0,60 (60\%) faktor 
lain yang berhubungan dengan IMD yang tidak termasuk dalam analisis model 3 .

\section{Analisis model 4}

Model 4 menunjukkan hubungan variabel metode persalinan dan IMD, serta besarnya kontribusi variabel penyakit ibu dan dukungan tenaga kesehatan. Pada model ini hubungan metode persalinan dan IMD setelah dikontrol dengan variabel penyakit ibu dan dukungan tenaga kesehatan hasilnya tetap bermakna $(R R=3,1$; $95 \% \mathrm{Cl}=1,42-6,89)$, artinya proporsi IMD lebih besar 3,1 kali pada wanita yang melahirkan dengan metode persalinan pervaginam dibandingkan pada wanita yang melahirkan dengan metode persalinan seksio sesarea. Model ini dapat memprediksi IMD sebesar $40 \%$. Hal ini ditunjukkan oleh nilai $R^{2}$ (koefisien determinasi) yaitu 0,4068 , artinya sebesar $40 \%$ dapat dijelaskan oleh variabel metode persalinan, penyakit ibu dan dukungan tenaga kesehatan dalam memprediksi pelaksanaan IMD. Terdapat 0,60 $(60 \%)$ faktor lain yang berhubungan dengan IMD yang tidak termasuk dalam analisis model 4.

\section{Hubungan metode persalinan dengan inisiasi menyusu dini}

Pada hasil analisis bivariat ditemukan bahwa proporsi IMD lebih besar pada wanita yang melahirkan dengan metode persalinan pervaginam dibandingkan wanita yang melahirkan dengan metode persalinan seksio sesarea. Analisis bivariat menunjukkan hubungan yang bermakna antara metode persalinan dengan IMD, di mana IMD lebih besar 4,9 kali pada wanita yang melahirkan dengan metode persalinan pervaginam dibandingkan pada wanita yang melahirkan dengan metode persalinan seksio sesarea. Hasil analisis multivariat dengan menggunakan analisis regresi binomial menunjukkan hubungan bermakna antara metode persalinan dengan IMD $(\mathrm{RR}=4,9 ; 95 \% \mathrm{Cl}=2,16$ 11,31). Hasil penelitian ini sesuai dengan penelitian di Melbourne, Australia yang menunjukkan bahwa seksio sesarea merupakan hambatan dalam melakukan IMD dibandingkan dengan persalinan pervaginam dengan atau tanpa bantuan instrumen $(p<0,001)(12)$.

Penelitian yang dilakukan di Meksiko juga menunjukkan bahwa ada hubungan bermakna antara metode persalinan dengan IMD, di mana seksio sesarea merupakan faktor risiko untuk tidak IMD dan untuk menyusui kurang dari 1 bulan (13). Namun hasil penelitian ini berlawanan dengan hasil penelitian di Brazil yang menunjukkan bahwa proporsi IMD pada bayi yang dilahirkan dengan metode persalinan pervaginam dibandingkan bayi yang dilahirkan dengan seksio sesarea elektif adalah sama (15). Seksio sesarea elektif biasanya menggunakan anestesi regional. Hal tersebut memungkinkan ibu untuk tetap terjaga saat operasi dan sesudah operasi, sehingga memungkinkan untuk terjadinya kontak awal antara ibu dan bayi segera setelah kelahiran. Jika kontak awal antara ibu dan bayi bisa dilakukan maka IMD akan dapat terlaksana dengan baik (18). Pendapat ini sesuai dengan hasil wawancara mendalam dengan tenaga kesehatan, yaitu sebagai berikut:

“...Mana mungkin pasien sesar bisa IMD. Mmm... tapi kalau anestesinya spinal mungkin masih bisa ya...."(IT.2)

"...IMD mau partus spontan atau SC bisa-bisa aja. Tapi seksio yang anestesi regional Iho..."(IT.3)

Berdasarkan hasil wawancara mendalam tersebut terlihat bahwa tenaga kesehatan berpendapat bahwa untuk IMD pada postseksio sesarea lebih mungkin untuk dilakukan bila anestesi yang digunakan pada saat seksio sesarea adalah anestesi regional. Pada data penelitian ini juga menunjukkan bahwa subjek yang melahirkan dengan seksio sesarea dan berhasil IMD adalah subjek yang dioperasi dengan menggunakan teknik anestesi regional. Dewasa ini, praktik anestesi modern lebih sering menggunakan teknik anestesi regional (regional anaesthesia) dibandingkan teknik anestesi umum (general anaesthesia) terutama pada kasus-kasus kebidanan seperti seksio sesarea. Namun di negara berkembang penggunaan teknik anestesi regional ini sangat dipengaruhi oleh beberapa faktor, di antaranya yaitu kurangnya persediaan alat atau obat anestesi regional karena kondisi ekonomi rumah sakit yang terbatas dan kurangnya ahli anestesi yang menguasai teknik anestesi regional (19).

\section{Hubungan penyakit ibu dengan inisiasi menyusu dini}

Pada hasil analisis bivariat ditemukan bahwa proporsi IMD lebih besar pada ibu yang tidak memiliki penyakit dibandingkan ibu yang memiliki penyakit. Hasil analisis bivariat menunjukkan bahwa variabel penyakit ibu berhubungan signifikan dengan IMD baik secara statistik maupun praktis, di mana proporsi IMD lebih besar 3,6 kali pada ibu yang memiliki penyakit dibandingkan ibu yang tidak memiliki penyakit. Hal ini sejalan dengan penelitian di Mesir yang menunjukkan bahwa penyakit ibu adalah salah satu faktor risiko yang menghambat IMD (20).

Hasil analisis multivariat, variabel penyakit ibu setelah dianalisis bersama-sama antara variabel bebas dengan variabel terikat secara praktis menunjukkan hasil yang signifikan. Hal tersebut juga terlihat dari hasil Indepth interview dengan subjek, sebagai berikut:

“... waktu hamil nggak ada penyakit apa-apa... tapi masuk bulan ke-9 sampai pas mau melahirkan, tekanan darah saya naik... Begitu anak saya lahir langsung aja dibawa sama bidannya... sampai sekarang saya belum lihat anak saya ..."(IR.3) 
“...Saya udah dikasih duviral dari umur kehamilan 35 minggu... CD4 saya terakhir 184... Saya pernah baca IMD di majalah...tapi dokter bilang saya nggak usah menyusui..." (IR.4).

Berdasarkan hasil wawancara mendalam tersebut terlihat bahwa penyakit ibu seperti HIVIAIDS dan preeklamsi merupakan salah satu faktor yang menghambat pelaksanaan IMD.

\section{Hubungan dukungan tenaga kesehatan dengan IMD}

Pada analisis bivariat ditemukan bahwa proporsi IMD lebih besar pada ibu yang mendapatkan dukungan tenaga kesehatan yang tinggi dibandingkan ibu yang mendapat dukungan tenaga kesehatan yang rendah. Analisis bivariat menunjukkan bahwa dukungan tenaga kesehatan mempunyai hubungan yang signifikan dengan IMD. Hal ini sejalan dengan hasil penelitian di Switzerland tahun 2005, bahwa bayi yang lahir di rumah sakit dengan dukungan tenaga kesehatan yang tinggi akan lebih besar kemungkinannya untuk IMD dibandingkan dengan yang lahir di rumah sakit dengan dukungan tenaga kesehatan yang rendah (21).

Begitu pula dengan penelitian yang dilakukan di Brazil didukung tenaga kesehatan yang tinggi yang dimiliki oleh rumah sakit yang menerapkan program Baby Friendly Hospital Initiative (BFHI) menunjukkan peningkatan angka IMD (22). Pada hasil analisis multivariat, variabel dukungan tenaga kesehatan setelah dianalisis bersama dengan variabel bebas dan variabel terikat menunjukkan hubungan yang signifikan baik secara praktis maupun statistik. Hal ini didukung oleh beberapa pendapat di antaranya peneliti dari Middlesex Hospital, Middletown, Connecticut Amerika Serikat, yang mengatakan bahwa kunci utama dari kesuksesan program IMD dan ASI eksklusif adalah dukungan tenaga kesehatan (23).

Demikian pula halnya dengan penelitian yang dilakukan di Jakarta pada tahun 2003 menyimpulkan bahwa keberhasilan IMD terletak pada penolong persalinan, karena pada 30 menit pertama setelah lahir peran penolong persalinan sangat dominan. Bila ibu difasilitasi oleh penolong persalinan untuk memeluk bayinya, maka interaksi antara ibu dan bayi segera terjadi sehingga IMD dapat terlaksana dengan baik (8). Namun fakta yang ditemukan oleh hasil penelitian yang menggunakan data dari 33 provinsi di Indonesia tahun 2007 menyebutkan bahwa wanita yang memperoleh perawatan pascamelahirkan (postnatal care) oleh dokter umum atau dokter spesialis memiliki probabilitas menyusui lebih singkat dibanding wanita yang dirawat oleh bidan. Namun lain halnya dengan wanita yang dirawat oleh dukun serta yang tidak mendapatkan perawatan pascamelahirkan akan lebih tinggi probabilitasnya untuk menyusui lebih lama dibandingkan wanita yang mendapat perawatan pascamelahirkan oleh dokter umum, spesialis maupun bidan (11). Hal ini menunjukkan bahwa di Indonesia dukungan tenaga kesehatan masih sangat kurang dalam menyukseskan program pemberian ASI eksklusif yang dicanangkan pemerintah, termasuk dalam hal IMD sebagai salah satu faktor keberhasilan pemberian ASI eksklusif.

Padahal dukungan tenaga kesehatan sangat diperlukan untuk meningkatkan keberhasilan IMD, terutama pada persalinan seksio sesarea dan persalinan pervaginam dengan bantuan instrumen, seperti dibuktikan oleh hasil penelitian di Taiwan tahun 2006 (14). Menurut hasil penelitian yang dipublikasikan di Amerika Serikat, dukungan oleh tenaga kesehatan ini sebaiknya diberikan pada saat prenatal maupun postpartum, karena hal tersebut terbukti secara efektif mendorong ibu melakukan IMD dan melanjutkan pemberian ASI (24). Hasil penelitian ini juga sesuai dengan hasil wawancara mendalam dengan tenaga kesehatan yaitu sebagai berikut:

“...Setelah bayi lahir saya segera pacu mereka untuk menyusui. Saya juga sudah mulai IMD pada pasienpasien yang sesar. Menurut saya tidak masalah selagi bayinya tidak bermasalah ya. ..."(IT.4)

“...Saya selalu melakukan IMD pada pasien yang partus normal... kecuali pada bayi-bayi yang apgarnya jelek atau bayi-bayi yang kecil. Sudah rutinitas kali ya, jadi sudah biasa aja, ga repot ah... Kalau pas kita sibuk misalnya pas barengan partus semua pasiennya, ya tenang aja... Kan ada suami pasien atau ibunya yang bisa jagain bayinya, kita tinggal suruh aja mereka jagain bayinya..."(IT.5)

Berdasarkan hasil wawancara mendalam terlihat bahwa bila ada dukungan dari tenaga kesehatan, maka IMD dapat terlaksana baik pada postpartum normal maupun pada postpartum seksio sesarea.

\section{KESIMPULAN DAN SARAN}

Proporsi IMD pada wanita yang melahirkan dengan metode persalinan pervaginam lebih besar, dibandingkan pada wanita yang melahirkan dengan seksio sesarea. Metode persalinan mempunyai hubungan yang signifikan dengan IMD. Dukungan tenaga kesehatan mempunyai hubungan yang signifikan dengan IMD. Penyakit ibu secara praktis berhubungan dengan IMD, sedangkan pengetahuan tidak mempunyai hubungan yang signifikan dengan IMD. Berdasarkan hasil wawancara mendalam diketahui bahwa dukungan tenaga kesehatan untuk IMD pada postpartum normal cukup tinggi, sedangkan dukungan tenaga kesehatan untuk IMD pada postpartum seksio sesarea masih rendah. Menurut pendapat para tenaga kesehatan IMD pada postseksio sesarea bisa terlaksana bila anestesi yang digunakan adalah anestesi regional.

Berdasarkan hasil penelitian di atas maka disarankan adanya regulasi dari Dinas Kesehatan yang mewajibkan 
setiap rumah sakit untuk memfasilitasi IMD pada setiap persalinan. Mengingat besarnya manfaat IMD maka rumah sakit perlu membuat prosedur standar operasional IMD, baik untuk persalinan pervaginam, seksio sesarea maupun persalinan pervaginam dengan bantuan instrumen (forsep dan vakum), sehingga dapat segera diimplementasikan oleh tenaga kesehatan. Selain itu rumah sakit perlu mengupayakan agar setiap persalinan seksio sesarea selektif menggunakan anestesi regional, sehingga IMD pada postseksio sesarea lebih mudah untuk dilaksanakan. Pemberian materi konseling pada saat ANC juga diharapkan tidak hanya mengenai ASI eksklusif saja, tetapi juga tentang IMD.

\section{RUJUKAN}

1. Badan Pusat Statistik (BPS), Badan Koordinasi Keluarga Berencana Nasional (BKKBN), Departemen Kesehatan (DEPKES), ORC Macro. USA: Survey Demografi dan Kesehatan Indonesia; 2003.

2. IBFAN Asia. The state of the world's breastfeeding report card: initiation of breastfeeding within 1 hour [serial online] 2007 [cited 2008 Apr 28]. Avalaible from: http://ibfanasia.org.

3. UNICEF. Initiation of breastfeeding by breast crawl. India: Unicef Maharastra 19, Harish Enterprises Parsee Panchayat Road, Andheri; 2007.

4. Departemen Kesehatan. Manajemen Iaktasi, buku pegangan bagi petugas kesehatan. Jakarta: Direktorat Jenderal Pembinaan Kesehatan Masyarakat; 2002.

5. Roesli U. Inisiasi menyusu dini. Jakarta: Pustaka Bunda; 2008.

6. Edmond KM, Zandoh C, Quigley MA, Etego SA, Agyei SO. Delayed breastfeeding initiation increases risk of neonatal mortality. Pediatrics 2006;117. 380-6.

7. Righard L, Alade MO. Effect of delivery room routines on success of breastfeed. Lancet 1990; 336. 1105-7.

8. Fikawati S, Syafiq A. Hubungan antara menyusui segera dan pemberian ASI eksklusif sampai dengan empat bulan. J Kedokteran Trisakti 2003; 22: 47-55.

9. Klaus M. Mother and infant: early emotional ties. Pediatrics 1998; 102. 1244.
10. Nissen E, Lilia G, Widstrom AM. Elevation of oxytocin levels in early post partum women. Acta Obstetric and Gynaecology 1995; 74: 530.

11. Wilopo SA. Pola, tren, dan perbedaan praktik menyusui di Indonesia: analisis deskriptif peran modernisasi dan budaya tradisional dari data Survei Demografi Kesehatan Indonesia. Jurnal Gizi Klinik Indonesia 2009; 6(1) : 42-51.

12. Murray HJR, Fisher JRW. Baby friendly hospital practices: cesarean section is persistentent barrier to early initiation of breastfeeding. Birth 2002; 29: 124-31.

13. Escamilla RP, Radovan IM, Dewey KG. The association between cesarean delivery and breastfeeding outcomes among mexican women. Am J Public Health 1996; 86: 832-6.

14. Chien LY, Tai CJ. Effect of delivery method and timing of breastfeeding initiation on breastfeeding outcomes in Taiwan. Birth 2007; 34: 123-30.

15. Victora CG, Huttly, SRA, Barros FC, Vaughan JP. Caesarean section and duration of breastfeeding among brazilians. Arch Dis Child 1990; 65: 632-4.

16. Patel RR, Liebling RE, Murphy DJ. Effect of operative delivery in the second stage of labour on breastfeeding success. Birth 2003; 30(4): 255-60.

17. Lemeshow S, Hosmer DWJ, Klar J, Lwanga SK. Besar sampel dalam penelitian kesehatan. Terjemahan Pramono D, Kusnanto H. Yogyakarta: Gadjah Mada University Press; 1997.

18. Afolabi BB, Lesi FA, Merah NA. Regional versus general anaesthesia for cesarean section. Cohrane Database of Systematic Reviews, issue 4; 2006.

19. Schnittger T. Regional anaesthesia in developing countries. Anaesthesia 2007; 62: 44-7.

20. Hakim Al, Ashmawy Al. Breastfeeding patterns in a rural village in Giza Egypt. Am J Public Health 1992; 82(5): 731-2.

21. Merten S, Dratva J, Liebrich UA. Do baby friendly hospitals influence breastfeeding duration on a national level?. Pediatrics 2005; 116: 702-8.

22. Braun MLG, Soares, MEM, Giugliani C, Oliveira PD, Danelon CMM. Evaluation of the impact of the baby friendly hospital initiative on rates of breastfeeding. Am J Public Health 2003; 93 (8): 1277-9.

23. Sinusas K, Gagliardi A. Initial management of breastfeeding. Am Fam Physician 2001; 64: 981-8.

24. Shealy KR, Li R, Benton DS, Grummer SLM. The CDC guide to breastfeeding interventions. Centers for Disease Control and Prevention. USA: US Departement of Health and Human Services; 2005. 